\title{
Analisis Resiko dan Pengembalian Hasil pada Perbankan Syariah: Aplikasi Metode VaR dan RAROC pada Bank Syariah Mandiri
}

\author{
Oleh: Yudho Prabowo ${ }^{1}$
}

\begin{abstract}
The aim of this research is to comprehend the size of financial risk of investment on Islamic bank, using Value at Risk ( $V$ aR) and Risk Adjusted Return on Capital (RAROC) approaches. $V a \mathrm{R}$ is employed to measure the net return of mudharabah deposit, meanwhile $\mathrm{RAROC}$ is used for measuring the net bank profitability.

This research is expected to give information for investors about financial and capital risk of their investment on Islamic banking industry, in term of deposits, share or Islamic bond. The object of this research is the financial reports of Bank. Syariah Mandiri (BSM) for three years, 2004 to 2006.

$\mathrm{VaR}$ analysis shows that return on Mudharabah deposit at the BSM is stable enough for the period of observation. It means that the loss potential is low. In 2006, The relationship between VaR (zero) and gross expected return on Mudharabah deposit for three months is prospective if it is compared by 2004 and 2005 years. On the other hand, RAROC analysis shows that the profit potential of BSM has been declined during three years, 2004 to 2006. The low level and fluctuation of the level of non-performing financing (NPF) already brought BSM to the lower capital risk.

Keywords: Investment, Value at Risk, Risk Adjusted Return on Capital, mudharabah deposits, potential loss, Bank Syariah Mandiri
\end{abstract}

\section{Pendahuluan}

Islam mengajarkan kepada umatnya untuk melakukan aktivitas kerja, kerja dilakukan untuk mengembangkan modal. Islam juga mengajarkan kepada umatnya untuk tidak menyimpan uang di bawah bantal. Dengan demikian, Islam adalah agama yang mendorong umatnya untuk selalu melakukan investasi kekayaan (hartanya) ${ }^{2}$. Dalam sistem ekonomi Islam, investasi dapat mengurangi kemiskinan dan meningkatkan income dengan cara memanfaatkan harta secara produktif. Kegiatan investasi yang sesuai dengan syariah Islam adalah usaha untuk menghasilkan kehidupan yang mulia (falab), memberikan manfaat (maslahab) dan menghindari cara investasi yang dilarang, yaitu riba, gharar dan maysir. Namun demikian, investasi yang produktif dapat dilakukan dengan saling bekerjasama dan profesional dalam melaksanakan prinsip tujuan utama syariat.

${ }^{1}$ Alumni Prodi Ekonomi Islam UII, email: bass_b4ss@yahoo.co.id.

${ }^{2}$ Iwan P. Pontjowinoto, "Investasi dalam Reksadana Syari'ah", Makalah Dialog Ekonomi Syari'ah, Yogyakarta, Agustus 1997. hal. 1.

90 La_Riba

JURNAL EKONOMI ISLAM

Volume III, No. 1, Juli 2009 
Yudho Prabowo: Analisis Resileo dan Pengembalian Hasil...

Dalam Islam, investasi ditentukan oleh beberapa variabel diantaranya adalah ekspektasi keuntungan pada sebuah projek, pendapatan dan kondisi perekonomian (bukan oleh tingkat bunga yang selama ini dikenal dalam teori ekonomi konvension) $)^{3}$. Keputusan investasi bagi seorang investor menyangkut masa akan datang yang mengandung ketidakpastian, yang berarti mengandung unsur risiko bagi investor. Pengetahuan tentang risiko merupakan suatu hal yang penting dimiliki oleh setiap investor maupun calon investor ${ }^{4}$.

Karim (2006) mengatakan bahwa instrumen investasi syariah merupakan saat paling tepat pada tahun 2007 karena tahun 2006 perbankan syariah mengalami kesulitan yang disebabkan Bank Indonesia sedang pasang suku bunga tinggi. Ini membuat bank syariah kalah bersaing dengan bank konvensional yang produk deposito tersebut mampu memberikan return yang bagus. Pada tahun $2007 \mathrm{BI}$ rate mengalami penurunan sehingga terjadi sebaliknya, investasi di instrumen perbankan syariah menjadi lebih menguntungkan ${ }^{5}$.

Dalam pandangan Islam, investasi dasar yang perlu diketahui dalam perbankan syariah yang termasuk produk penghimpunan dana (funding adalah deposito. Berdasarkan Undang-undang Nomor 10 Tahun 1998 tentang Perubahan atas Undang-undang Nomor 7 Tahun 1992 tentang Perbankan, yang dimaksud dengan deposito berjangka adalah simpanan yang penarikannya hanya dapat dilakukan pada waktu-waktu tertentu munurut perjanjian antara penyimpan dengan bank yang bersangkutan. Adapun yang dimaksud dengan deposito syariah adalah deposito yang dijalankan berdasarkan prinsip syariah. Dalam hal ini, Dewan Syariah Nasional (DSN) telah mengeluarkan fatwa yang menyatakan bahwa deposito yang dibenarkan adalah deposito yang berdasarkan prinsip mudharabab ${ }^{6}$.

Konsep bank syariah mengarahkan kepada perolehan pengembalian hasil tidak pasti dan tidak tetap. Namun demikian, konsep investasi tersebut adalah usaha yang menanggung risiko, artinya setiap kesempatan untuk memperoleh keuntungan dari usaha yang dilaksanakan, didalamnya terdapat pula risiko untuk menerima kerugian, maka antara nasabah atau deposan dan bank sama-sama saling berbagi baik keuntungan maupun risiko ${ }^{7}$.

Manajemen risiko dalam industri perbankan sudah menjadi bagian penting dalam operasionalisasi risiko yang dihadapi perbankan. Fungsi bank sebagai sarana intermediasi dana dari pihak yang surplus menuju pihak yang deficit menyebabkan bank mempunyai karakteristik umum sebagai pengelola risiko transaksi keuangan ${ }^{8}$.

${ }^{3}$ Ali Sakti, “Konsep Investasi dalam Islam” Ekonomi Islam, 25 September 2007.

${ }^{4}$ Jayani Nurdin, "Risiko Investasi pada Saham Properti di Bursa Efek Jakarta”, Usahawan, No. 03 Th. XXVIII (Maret 1999), hal. 1 kolom I.

5Iklan Sirkulasi Surat Pembaca, Lebih Untung Inves di Tabungan Syariah, Tuesday, 30 Januari 2007.

${ }^{6}$ Fatwa Dewan Syariah Nasional Nomor 03/DSN-MUI/IV/2000.

${ }^{7}$ Ibid.

${ }^{8}$ Putu Anom Mahadwartha, "Konflik Keagenan Dalam Kebijakan Penetapan Nilai Value-at-Risk Pada Industri Perbankan", Manajemen USAHAW AN Indonesia, Lembaga Manajemen Fakultas Ekonomi Universitas Indonesia, Jakarta, No. 09/TH. XXXI (September 2002), hal. 1. 
Yudho Prabowo: Analisis Resiko dan Pengembalian Hasil...

Transaksi keuangan yang menimbulkan risiko pada umumnya ialah memberikan kredit dan menampung simpanan dari pihak ketiga (nasabah). Pemberian kredit menimbulkan risiko kredit atau credit risk sedangkan simpanan pihak ketiga menimbulkan liquidity risk?

Dari uraian di atas dapat diketahui bahwa manajemen risiko adalah bagian terpenting bagi investor (deposan) untuk melakukan investasi. Pengelolaan risiko ini mencakup antara cakupan identifikasi risiko, pengukuran risiko, pengelolaan risiko, pembatasan risiko dan pemantauan risiko. Melalui pendekatan ini maka bobot risiko dan bobot pengembalian hasil dapat terukur. Sehingga investor akan memperoleh peluang return atau nilai bagi hasil yang optimal dan juga prospektif.

Oleh karena itu, dalam ckondisi tersebut diperlukan untuk melakukan sebuah penelitian tentang seberapa besar bobot bersih (net-weights) risiko yang dihadapi oleh investor (deposan) sebagai shabibul maal dan seberapa besar bobot bersih perolehan pengembalian hasil (return) investasi di Bank Syariah Mandiri yang berperan dengan baik dalam mengelola dan memanfaatkan dana (mudharib) ke dalam berbagai usaha, investasi atau pembiayaan. Adanya upaya untuk memahami seberapa besar bobot bersih risiko dan pengembalian hasil, penelitian ini akan menganalisis dengan metode alternatif untuk mengukur bobot aktual tingkat risiko dan tingkat pengembalian hasil investasi di Bank Syariah Mandiri. Metode alternatif yang dapat digunakan untuk mengetahui parameter tersebut yaitu pendekatan $V$ alue at Risk (VaR) dan pendekatan Risk Adjusted Return on Capital (RAROC).

VaR paling umum digunakan sebagai alat untuk mengukur dan mengontrol risiko pasar (market risk). VaR mengukur potensi kerugian dari suatu periode waktu yang diberikan dengan beberapa tingkat kepercayaan statistik. Dengan kata lain, angka VaR adalah quantile distribusi keuntungan dan kerugian portofolio. VaR diperkenalkan dan dipopulerkan pada tahun 1994 oleh J.P. Morgan's dengan software Risk Metrics dan sejak kemudian VaR telah menjadi suatu konsep standar dalam manajemen risiko ${ }^{10}$.

RAROC merupakan suatu metrik kinerja yang mempertimbangkan persamaan total risiko dan return perbankan. Selama periode jangka panjang, risiko dan return mempunyai hubungan. Seperti ROE, RAROC memfokuskan pada keduanya investasi perbankan dan kinerja pendapatan. Bagaimanapun, RAROC memiliki benefit plus dari penyampaian return berdasarkan pada tingkat spesifik risiko yang diambil ${ }^{11}$.

Dalam paper ini, metodologi VaR digunakan untuk mengukur seberapa besar bobot bersih risiko atau potensi kerugian investor (deposan) dalam investasi deposito mudharabah selama horizon waktu $\mathrm{t}$ (setahun) dengan tingkat kepercayaan $(99 \%)$. Sementara itu, metodologi RAROC digunakan untuk mengukur seberapa

${ }^{9}$ P. Jorion, The New Benchmark for Controlling Derivatives Risk: Value at Risk, (Irwin Professional Publishing, 1997)

${ }^{10}$ S. Pichler and K. Selitsch, (1999): A Comparison of Analytical VaR Methodologies for Portfolios That Include Options, Working Paper TU Wien, available at: http://www.gloriamundi.org, hal. 1.

${ }^{11}$ Mary Brookhart, Bank Asset/Liability Management, The Case for Utilizing Risk-Adjusted Capital as a Key Performance Measure, (2007), hal. 1.

92 La Riba

JURNAL EKONOMI ISLAM

Volume III, No. 1, Juli 2009 
Yudho Prabowo: Analisis Resiko dan Pengembalian Hasil...

besar bobot bersih pengembalian hasil investasi di Bank Syariah Mandiri selama setahun.

Data paper ini adalah data dari Bank Syariah Mandiri meliputi data laporan keuangan dan indikasi tingkat ekuivalen (equivalent rate) deposito mudharabah. Dengan penaksiran kuantitatif, pendekatan VaR dan RAROC diperlukan menggunakan analisis statistik terhadap data-data tersebut yang dijadikan sebagai acuan analisis tingkat risiko dan pengembalian hasil investasi di Bank Syariah Mandiri.

\section{Tujuan Penelitian}

Berkaitan dengan latar belakang masalah di atas, paper ini bertujuan:

1. Untuk mengetahui risiko investasi deposito mudharabah di Bank Syariah Mandiri diukur dengan pendekatan VaR

2. Untuk mengetahui tingkat pengembalian hasil investasi di Bank Syariah Mandiri di Indonesia apabila diukur dengan pendekatan RAROC.

\section{Manfaat Penelitian}

Penelitian ini diharapkan memberikan manfaat bagi pengambilan keputusan investasi di perbankan syariah pada umumnya, terutama di dalam bentuk deposito dan investasi ekuitas. Kinerja rata-rata keuntungan yang ditawarkan oleh perbankan belum tentu mencerminkan keuntungan bersih (net return). Evaluasi melalui VaR dan RAROC ini merupakan suatu metode untuk mncari cermin return bersih investasi.

\section{Kerangka Konseptual Penelitian}

\section{A. Investasi, return, dan risiko keuangan}

Investasi adalah menanamkan atau menempatkan aset, baik berupa harta maupun dana, pada suatu yang diharapkan akan memberikan hasil pendapatan atau akan meningkatkan nilainya di masa mendatang. Sedangkan investasi keuangan adalah menanamkan dana pada suatu surat berharga yang diharapkan akan meningkat nilainya di masa mendatang ${ }^{12}$.

Agar modal (asset) mengalami peningkatan dalam berinvestasi, Umer Chapra mengemukakan beberapa hal yang perlu diperhatikan para calon investor, yaitu sikap tidak berlebihan terhadap pengeluaran, membatasi uang yang tidak terpakai, menggunakan tabungan secara efisien dan memanfaatkan sumber daya dan peran pemerintah ${ }^{13}$.

${ }^{12}$ Iwan P. Pontjowinoto, Prinsip,. hal. 45

${ }^{13}$ M. Umer Chapra, Al-Qur'an Menuju Sistem Monoter yang Adil, (terjemahan) Yogyakarta: PT. Dana Bhakti Prima 
Yudho Prabowo: Analisis Resiko dan Pengembalian Hasil...

Van Deer Haidjen (1996) telah membagi ketidakpastian menjadi 3 kategori, yaitu:

a. Risk, kemungkinannya memiliki preseden historis dan dapat dilakukan estimasi probabilitas untuk hasil yang mungkin muncul.

b. Structural uncertainties, kemungkinan terjadinya suatu bersifat unik, tidak memiliki preseden di masa lalu, tetapi tetap mungkin terjadi dalam logika kausalitas.

c. Unknowables, yaitu kejadian yang secara ekstrim kemunculannya tidak terbayangkan sebelumnya.

Jadi dalam kategori ini risiko (risk) adalah sebutan bagi kemungkinan kejadian yang ada preseden historisnya dan mengikuti suatu distribusi probabilitas. Karenanya, risiko ini dapat diperkirakan setidaknya secara teoritis. Sementara itu Al Suwailem (1999) menggunakan kata risiko untuk segala sesuatu yang tejadi secara tidak pasti di masa depan. Ia membaginya dalam 2 kategori, yaitu:

a. Pasive risk, yaitu risiko yang terjadi di mana benar-benar tidak terdapat perkiraan dan perhitungan yang dapat dipakai. Jadi, hal ini benar-benar suatu teka-teki yang sama sekali tidak diketahui jawabannya. Perkiraan atas risiko ini hanya mengandalkan keberuntungan (game of chance), karenanya seseorang hanya dapat bersifat pasif.

b. Responsive risk, yaitu risiko yang munculnya memiliki penjelasan kausalitas dan memiliki distribusi probabilitas. Risiko jenis ini, karenanya dapat diperkirakan dengan menggunakan cara-cara tertentu. Memperkirakan risiko responsive ini sering disebut pula game of skill, karena perkiraanya didasarkan atas skill tertentu.

Risiko dalam sistem profit-share (bagi hasil) tidak terdapat suatu fixed and certain return sebagaimana bunga, tetapi dilakukan loss and profit sharing berdasarkan produktifitas nyata dari dana tersebut. Meskipun nisbah bagi hasil disepakati pada saat awal, tetapi perolehan riil dari bagi hasil ini baru diketahui setelah dana benarbanar menghasilkan. Jadi, hal yang bersifat pasti dari sistem ini adalah nisbah bagi hasilnya, bukan nilai riil bagi hasilnya. Terdapat kemungkinan fluktuasi dalam bagi hasil yang nyata, tergantung pada produktifitas nyata dari pemanfaatan dana ${ }^{14}$.

Di sisi lain, pengembalian hasil (return) dapat didefinisikan sebagai tingkat keuntungan yang diperoleh atau diharapkan dari suatu investasi selama satu periode waktu, yang akan diperoleh di masa mendatang. Return merupakan kompensasi atas risiko yang harus ditanggung oleh investor atas investasi yang dilakukannya ${ }^{15}$. Tingkat pengembalian hasil yang diharapkan (expected rate of return) adalah perolehan nilai rata-rata dari distribusi probabilitas untuk hasil-hasil yang mungkin dicapai ${ }^{16}$.

${ }^{14}$ M. B. Hendrie Anto, Pengantar Ekonomika Mikro Islami, , cet. I Yogyakarta: EKONOSIA, Oktober 2003), hal. 250.

15Namora, "Perbandingan Market Performance dan Karakteristik Keuangan Perusahaan Sektor Aneka Industri dengan Sektor Properti - Real Estat, Tesis, Program Studi Magister Manajemen Program Pasca Sarjana Universitas Pelita Harapan Jakarta (2006), hal 13.

${ }^{16} \mathrm{~J}$. Fred Weston, Eugene F. Brigham, Essentials of Finance, Erlangga, hal. 117. 
Yudho Prabowo: Analisis Resiko dan Pengembalian Hasil...

Perbedaan antara return yang diharapkan (return yang diantisipasi investor di masa mendatang) dengan return yang benar-benar diterima (return yang diperoleh investor) merupakan risiko yang harus selalu dipertimbangkan dalam proses investasi ${ }^{17}$.

\section{B. Hubungan Risiko dan Pengembalian Hasil}

Hubungan return dan risiko searah dan linier, artinya semakin besar return yang diharapkan, maka semakin besar pula risiko yang harus ditanggung ${ }^{18}$.

Setiap risiko investasi selalu mempunyai kemungkinan memperoleh positive return, negative return, atau no return. Dalam transaksi bagi hasil hubungannya bukan antara penjual dan pembeli, atau penyewa dan yang menyewakan. Yang ada adalah hubungan antara pemodal dan yang memproduktifkan modal. Jadi tidak ada pihak yang telah melaksanakan kewajibannya, tapi masih tertahan haknya. Si pemodal telah melaksanakan kewajibannya, yaitu memberikan sejumlah modal, yang memproduktifkan modal juga telah melaksanakan kewajibannya, yaitu memproduktifkan modal tersebut. Hak bagi mereka berdua akan timbul ketika usaha memproduktifkan modal tersebut telah menghasilkan pendapatan atau keuntungan. Hak mereka adalah berbagi hasil atas pendapatan atau keuntungan, sesuai kesepakatan awal, apakah bagi hasil itu akan dilakukan berdasarkan pendapatan atau berdasarkan keuntungan ${ }^{19}$.

\section{Metode Penelitian}

\section{A. Desain Penelitian}

Metode penelitian yang digunakan oleh penulis dalam menyusun penelitian ini adalah Metode Penelitian Empiris dengan menggunakan desain penelitian kuantitatif. Kuantitatif adalah data yang diukur dalam suatu skala numerik (angka) yang dapat dianalisis dengan menggunakan analisis statistik ${ }^{20}$. Metodologi ini menggambarkan analisis statistik dimana penulis mengetahui bobot risiko dan pengembalian hasil investasi di Bank Syariah Mandiri Indonesia dengan menggunakan pendekatan Value at Risk (VaR) dan Risk Adjusted Return on Capital (RAROC).

\section{B. Alat Analisis}

Penelitian ini menggunakan dua alat analisis yaitu VaR dan RAROC. Value at Risk (VaR) adalah sebuah konsep yang digunakan untuk mengukur risiko dalam risk management. Secara sederhana VaR ingin menjawab pertanyaan "seberapa besar (dalam persen atau sejumlah uang tertentu) investor dapat mengalami kerugian

\footnotetext{
${ }^{17}$ Op.Cit.

${ }^{18}$ Namora, Perbandingan., hal. 16.

${ }^{19}$ Adiwarman Karim, Bank Islam., hal. 334.

${ }^{20}$ Mudrajad Kuncoro, Metode Kuantitatif Teori dan Aplikasi untuk Bisnis dan Ekonomi, Cet 2 (Yogyakarta: UPP AMP YKPN, 2004), hal. 23.
} 
Yudho Prabowo: Analisis Resiko dan Pengembalian Hasil...

selama waktu investasi $T$ dengan tingkat kepercayaan sebesar $\alpha$ ". Dari pertanyaan tersebut, secara sederhana dapat dilihat adanya tiga variabel yang penting yaitu: besar kerugian, selang waktu, dan besar tingkat kepercayaan ${ }^{21}$.

Jorion (1996) sebagai salah satu pendukung VaR mengatakan bahwa transparansi akan semakin baik karena VaR secara konsisten mengukur pengaruh dari lindung nilai (hedging)terhadap risiko total. VaR memberikan penekanan pada keseluruhan risiko, dibandingkan dengan pengukuran tradisional yang lebih menekannya pada risiko per transaksi individual. Keunggulan inilah yang mendorong penggunaan $\mathrm{VaR}^{22}$.

RAROC adalah suatu ukuran profitabilitas yang telah disesuaikan dengan besarnya risiko bahwa pengelolaan memungkinkan untuk alokasi modal, menghubungkan biaya modal dan menyangkut pada risiko kredit (credit risk), risiko pasar (market risk) dan risiko operasional (operational risk) terhadap berbagai macam transaksi, klien dan jalur usaha ${ }^{23}$.

Bank sebagai institusi keuangan menghadapi bermacam-macam risiko keuangan, sebagai berikut ${ }^{24}$

1. Market risk, merupakan perubahan nilai aset bersih karena perubahan dalam faktor-faktor ekonomi seperti suku bunga, nilai tukar, harga saham dan harga komoditi

2. Credit risk, merupakan perubahan nilai aset bersih karena perubahan kemampuan pihak ketiga untuk memenuhi kewajibannya. Terkait dengan negara berkembang seperti Indonesia yang mempunyai obligasi pemerintah, manajemen akan mempertimbangkan besarnya spread kredit/obligasi, penentu perubahan nilai obligasi dan apakah resiko sovereign tergambar dalam spread ${ }^{25}$.

3. Operational risk, diakibatkan oleh biaya yang tiimbul karena kesalahan dalam melakukan transaksi seperti kesalahan settlement, kegagalan dalam memenuhi regulasi dan lainnya

4. Performance risk, menekankan pada kerugian karena kegagalan dalam mengawasi karyawan atau kegagalan dalam menggunakan metode pengukuran.

Risiko adalah suatu kejadian dimana muncul ukuran ketidakpastian (uncertainty) terhadap volatilitas atau pergerakan fluktuasi nilai equivalent rate bagi hasil. Investor (deposan) dapat memahami risiko melalui ukuran ketidakpastian yang dapat diamati dari preseden historis atau data historis mengenai laporan keuangan Bank Syariah Mandiri, hal ini dapat menunjukkan suatu kemungkinan bahwa nilai bagi hasil (return) aktual akan menyimpang dari nilai bagi hasil (return)

\footnotetext{
${ }^{21}$ D. Harper, Intoduction to Value at Risk (VAR). 2004, Investopedia. URL.

22P. Jorion, (1996), "Risk2: Measuring the Risk in Value at Risk," Financial Analysts Journal, 47-56.

${ }^{23}$ Experian Scorex, The New Basel Capital Accord Glossary of Terms, hal 5.

${ }^{24}$ D.H. Pyle (1997), "Bank Risk Management: Theory,” Risk Management and Regulation in Banking, 1-13.

${ }^{25}$ Dym, S. (1997), "Credit Risk Analysis for Developing Country Bond Portfolios: Applying Classical Tools to a New Asset Class," The Journal of Portfolio Management, 99-103.
} 
Yudho Prabowo: Analisis Resiko dan Pengembalian Hasil...

yang diharapkan. Aplikasi VaR terhadap investasi deposito mudharabah sebagai alat analisis untuk mengetahui bobot bersih risiko dan menjadikan peluang untuk memperoleh pengembalian hasil (return) yang optimal dan prospektif di masa mendatang.

\section{Metode Pengukuran VaR}

Metode pengukuran bobot bersih risiko deposito mudharabah dengan pendekatan VaR dapat dijelaskan sebagai berikut:

1. Metode pengukuran risiko dihitung dengan estimasi persentase kerugian potensial melalui VaR nilai absolut dan nilai relatif. Nilai VaR absolut adalah kerugian terhadap zero (nol) dan nilai VaR relatif adalah kerugian yang dibandingkan dengan rata-rata nilai pengembalian hasil yang diharapkan (expected return) $\mu^{26}$. Estimasi pendekatan VaR dapat dilihat dengan formulasi sebagai berikut:

\begin{tabular}{|l|}
\hline$V a \mathrm{R}($ mean $)=A 0 a \sigma \sqrt{ } T$ \\
\hline$V a \mathrm{R}($ zero $)=A 0(a \sigma \sqrt{ } T-\mu T)$ \\
\hline
\end{tabular}

Dimana A0 menunjukkan nilai yang dinvestasika pada tingkat pengembalian hasil (rate of return), a menunjukkan distribusi standar normal, $\sigma$ menunjukkan standar deviasi, T menunjukkan selang waktu dimana ditentukan dalam tahun, (sehingga dalam satu bulan menjadi $1 / 12$ ) dan $\mu$ menunjukkan tingkat pengembalian hasil yang diharapkan (expected return).

2. VaR absolute dan $\mathrm{VaR}$ relative menggunakan metode parametric yang dikalikan dengan dua parameter quantitatif yaitu tingkat kepercayaan (confidence level) dan horizon waktu disebabkan sifat pengukurannya adalah estimasi. Tingkat kepercayaan didasarkan pada nilai distribusi standar normal (a) yang dapat dicari dari tabel kurva normal sebesar 1.65 untuk tingkat kepercayaan $c 95 \%$ dan 2.33 untuk tingkat kepercayaan $99 \%{ }^{27}$. Mengukur VaR lebih baik menggunakan tingkat kepercayaan yang lebih tinggi. Berbagai macam tingkat kepercayaan memberikan informasi yang berguna mengenai distribusi tingkat pengembalian hasil (return) dan kerugian esktrim potensial ${ }^{28}$.

\begin{tabular}{|l||c|}
\multicolumn{1}{c|}{ Confidence } & \# of Standard Deviations ( $\sigma$ ) \\
\hline $95 \%$ (high) & $-1.65 \times \sigma$ \\
\hline $99 \%$ (really high) & $-2.33 \times \sigma$ \\
\hline
\end{tabular}

Sumber: D. Harper, tabun 2004.

${ }^{26}$ Ibid.

${ }^{27}$ Ibid.

${ }^{28}$ Philippe Jorion, Financial Risk. Manager Handbook, John Wiley \& Sons, Inc., Hoboken, New Jersey, 2003), hal. 252.

Volume III, No. 1, Juli 2009 
Yudho Prabowo: Analisis Resiko dan Pengembalian Hasil...

3. Tingkat pengembalian hasil yang diharapkan (expected return) digunakan untuk mengukur rata-rata estimasi atau perkiraan dari distribusi probabilitas yang diperoleh dari pendapatan nilai bagi hasil (return) deposito mudharabah. Terkait dengan penelitian ini, tingkat pengembalian hasil yang diharapkan dihitung dari variabel nilai rata-rata equivalent rate atau distribusi pendapatan bagi hasil deposito mudharabah dari periode bulanan dalam setahun (tahun 2004-2006).

4. Standar deviasi menunjukkan bahwa jika semakin besar standar deviasi dari pengembalian hasil, maka semakin besar variabel dari pengembalian hasil dan semakin tinggi risiko dari investasi tersebut. Hal ini dapat digunakan sebagai ukuran absolut dari variabilitas pengembalian hasil29. Dalam aplikasi penelitian ini, risiko investasi deposito mudharabah dapat dilihat secara total (total risk) melalui standar deviasi. Dimana standar deviasi mengukur persentase ukuran jarak atau fluktuasi dari variabel rata-rata nilai pengembalian hasil yang diharapkan. Pada aplikasinya, standar deviasi adalah jumlah kuadrat variabel nilai equivalent rate (distribusi pendapatan bagi hasil deposito mudharabah) (Xi) dikurangi variabel nilai rata-rata (mean) equivalent rate bagi hasil deposito mudharabah $(\underline{X} \imath)$ dibagi jumlah periode waktu $(\mathrm{N})$ bulanan dalam setahun (2004-2006).

\section{Metode Pengukuran RAROC}

Pengembalian hasil (return) adalah suatu laba bersih (netprofit) dalam ukuran presentase yang diperoleh dari suatu produktifitas dan pemanfaatan usaha Bank Syariah Mandiri yang diukur berdasarkan perbandingan tingkat keuntungan yang telah disesuaikan dengan besarnya risiko (risk adjusted return) dan modal yang telah disesuaikan dengan besarya risiko (risk adjusted capita).

Metode pengukuran bobot bersih pengembalian hasil investasi di Bank Syariah Mandiri dengan pendekatan RAROC dapat dijelaskan sebagai berikut:

1. Rasio RAROC menguji faktor risk adjusted return (RAR) dengan risk adjusted capital (RC). Dalam rasio ini, besarnya tingkat keuntungan dan modal telah disesuaikan dengan besarnya risiko, sehingga hal tersebut dapat memberikan penjelasan mengenai net profitabilitj ${ }^{30}$. Dalam perhitungan RAROC digunakan beberapa variabel yaitu variabel rata-rata keuntungan yang dihasilkan dari selisih antara jumlah penerimaan (total revenue) dengan jumlah biaya (total cost), variabel kerugian terekspektasi atau rata-rata kerugian (expected loss) dan variabel rata-rata kerugian terburuk atau maksimum (worst case loss) ${ }^{31}$. Secara keseluruhan, perhitungan pendekatan RAROC dapat dirumuskan sebagai berikut:

$$
\text { RAROC }=\frac{\text { Risk Adjusted Return }}{\text { Risk Capital }}=\frac{\text { TR-TC-EL }}{\text { WL-EL }}
$$

${ }^{29}$ C. James. Van Horne, John M. Wachowichz, JR, “Fundamentals of Financial Management”, (Pearson Education, 2005), hal 42.

${ }^{30}$ Ariane Chapelle, Yves Crama, Georges Hübner, Jean-Philippe Peters, Practical.,

${ }^{31}$ Tarriqullah Khan, Habib Ahmed, "Risk Management., hal 43. 
Yudho Prabowo: Analisis Resileo dan Pengembalian Hasil...

Dimana Risk Adjusted Return (RAR) menunjukkan pengembalian hasil yang disesuaikan dengan besarnya risiko dan Risk Capital (RC) menunjukkan besarnya modal yang disesuaikan dengan besarnya risiko.

2. Risk Adjusted Return (RAR). Pada variabel Risk Adjusted Return (RAR) menunjukkan adanya misleading (maksudnya kesalahan utama suatu strategi yang digunakan untuk mempercepat pembayaran utang atau penagihan untuk mengantisipasi pergerakan nilai tukar mata uang) ${ }^{32}$. Bankers Trust memasukkan kalkulasi aktual bahwa kegagalan pembayaran (defaults) kemungkinan terjadi pada debitur atau pihak yang menerima kucuran kredit. Namun demikian, Bankers Trust perlu mengurangi rata-rata kerugian (expected loss) dan ketentuan pengembalian hasil (deterministic return) pihak yang menerima kucuran kredit. Jika expected loss dapat diketahui maka tidak akan melibatkan suatu risiko ${ }^{33}$. Dalam penelitian ini, untuk mengetahui seberapa besar bobot bersih variabel RAR, ada tiga variabel untuk mengukur RAR yaitu variabel jumlah penerimaan (total revenue), variabel jumlah biaya (total cost) dan variabel rata-rata kerugian (expected loss). Secara keseluruhan TR, TC dan EL dapat dirumuskan sebagai berikut:

$R A R=T R-T C-E L$

Dimana:

RAR : Risk Adjusted Return

TR : Total Revenue

TC : Total Cost

EL : Expected Loss

a. Total Revenue (TR) dan Total Cost (TC) menunjukkan tingkat efisiensi, tingkat keuntungan, atau kerugian dan tingkat output yang optimal. Keuntungan atau profit merupakan selisih antara TR dengan TC atau diformulasikan dengan $(\pi=\mathrm{TR}-\mathrm{TC})$. Jika TR $>$ TC maka terdapat keuntungan, jika TR $<$ TC maka terdapat kerugian dan jika TR $=$ TC maka impas (break even $)^{34}$. Dalam penelitian ini, dimana selisih antara TR dengan TC menunjukkan rata-rata keuntungan atau kerugian Bank Syariah Mandiri yang diukur melalui variabel Laba Sebelum Pajak (earning before tax).

b. Expected Loss (EL) adalah rata-rata statistik (mean) ramalan tingkat kerugian yang disebabkan oleh kelalaian pada pihak yang menerima pinjaman kredit, kerugian nilai modal dan permasalahan operasional ${ }^{35}$. Dalam aplikasi penelitian ini, expected loss (EL) adalah variabel Pembiayaan Non Lancar(Non Performing Financings) pada Bank Syariah Mandiri dari periode bulanan dalam setahun (tahun 2004-2006).

${ }^{32}$ Sumadji P. Yudha Pratama, Rosita, "Kamus Ekonomi Lengkap”, (WIPRESS, 2006).

${ }^{33}$ M. Prokopczuk, S. Rachev and S. Truck, " Quantifying Risk in The Electricity Business: A RAROCbased Approach”, (October 11, 2004).

${ }^{34}$ M.B. Hendrie Anto, "Pengantar., hal. 255.

${ }^{35}$ Alistair Milne and Mario Onorato, "Apples and Pears: The Comparison of Risk Capital and Required Return in Financial Institution, (February 2007), hal 3.

Volume III, No. 1, Juli 2009 
Yudho Prabowo: Analisis Resiko dan Pengembalian Hasil...

3. Risk Capital (RC). Risk Capital adalah modal yang diperlukan untuk menutupi kebutuhan apabila menghadapi suatu masalah karena risiko menjadi kenyataan. Validitas Risk Capital dipertimbangkan terhadap sesuatu yang lebih buruk daripada pembayaran rata-rata kerugian (expected loss) ${ }^{36}$. Dimana RC menunjukkan besarnya modal yang disesuaikan dengan risiko. Ada dua variabel untuk mengukur RC yaitu variabel kerugian terburuk atau maksimum (worst case loss) dan variabel rata-rata kerugian dari pinjaman kredit (expected loss). WL dan EL dapat dirumuskan sebagai berikut:

$R C=W L-E L$

Dimana:

RC : Risk Capital

WL : Worst Case Loss

EL : Expected Loss

Variabel Worst Case Loss (WL) menunjukkan kemungkinan besar kerugian terburuk atau maksimum. Dalam penelitian ini, WL diukur melalui variabel rata-rata maksimum atau terburuk dari Pembiayaan Non-Lancar (NPF) pada Bank Syariah Mandiri dari periode bulanan dalam setahun (tahun 2004-2006). Namun demikian, warst case loss diestimasi dengan tingkat kepercayaan (confidence level c) yang telah ditentukan. Jika confidence level $95 \%$, hal tersebut terdapat probabilitas atau peluang sebesar 5\% bahwa kerugian aktual (actual loss) akan melebihi modal ekonomis (economic capita). Suatu kerugian yang tidak ditutup dengan confidence level merupakan risiko bencana besar (catastrophic risk) yang dihadapi oleh perusahaan ${ }^{37}$. Estimasi WL terhadap confidence level dapat dirumuskan sebagai berikut:

$$
\bar{X} \pm Z \underset{\sqrt{N}}{\underline{N}}
$$

Sumber: Murry R. Spiegel dan Larry J. Stephens, tabun 2004.

Dimana:

$$
\begin{aligned}
& \underline{\mathrm{X}}: \text { Expected loss } \\
& Z_{c}: \text { Tingkat kepercayaan } \\
& \sigma: \text { Standar deviasi } \\
& \mathrm{N}: \text { Jumlah nilai }
\end{aligned}
$$

Dalam penelitian ini, confidence level yang dihasilkan adalah $95 \%$ dari nilai $Z_{c}=$ 1.96 (lihat tabel statistik). Standar deviasi digunakan untuk mengukur kerapatan jarak atau fluktuasi dari suatu nilai variabel rata-rata (mean) kerugian atau expected loss

${ }^{36}$ M. Prokopczuk, S. Rachev abd S. Truck, Quantifying Risk in the Electricity Business: A RAROCbased Approach, October, 2004.

${ }^{37}$ Tarriqullah Khan, Habib Ahmed, Op.Cit, hal 43. 
Yudho Prabowo: Analisis Resileo dan Pengembalian Hasil...

(EL). Pada aplikasinya, standar deviasi diukur pada variabel rata-rata NPF Bank Syariah Mandiri dari periode bulanan dalam setahun (tahun 2004-2006).

Analisis data dalam penelitian ini diperkerjakan dengan pendekatan kuantitatif. Pengujian statistik perhitungan VaR menggunakan tingkat kepercayaan $c$ 99\% dan perhitungan RAROC dengan tingkat kepercayaan c 95\%. Dalam penelitian ini, untuk memudahkan perhitungan VaR dan RAROC meliputi rata-rata tingkat pengembalian hasil yang diharapkan (expected return), rata-rata kerugian (expected loss), rata-rata kerugian terburuk (worst case loss) dan standar deviasi.

\section{Analisis dan Pembahasan}

Paper ini membahas mengenai analisis $V$ alue at Risk (VaR) terhadap investasi deposito mudharabah berjangka (1, 3, 6 dan 12 bulan) dan analisis Risk Adjusted Return on Capital (RAROC) terhadap investasi di Bank Syariah Mandiri selama periode 2004-2006. Di dalam pembahasan ini, dijelaskan bagaimanakah risiko investasi deposito mudharabah apabila diukur dengan pendekatan VaR dan bagaimanakah pengembalian hasil investasi di Bank Syariah Mandiri apabila diukur dengan pendekatan RAROC.

\section{A. Hasil Analisis VaR}

Hasil analisis VaR mengindikasikan adanya hubungan atau pengaruh antara variabel rata-rata nilai gross expected return dengan variabel VaR (mean) dan variabel VaR (zero) selama periode observasi 2004-2006 sebagai berikut:

1. Apabila terdapat return yang besar dengan risiko yang kecil (low risk high return) berarti terdapat nilai prospektif.

2. Apabila hubungannya searah dan linier dimana terdapat return yang besar dengan risiko yang besar (high risk high return) atau pengembalian hasil yang kecil dengan risiko yang kecil (low risk low return) berarti terdapat nilai wajar.

3. Apabila terdapat return yang kecil dengan risiko yang besar (high risk low return) berarti terdapat nilai potensi kerugian.

Hasil Analisis VaR (zero) mencerminkan adanya selisih antara VaR (mean) dengan rata-rata nilai gross expected return dimana estimasi ini ditunjukkan pada formulasi $V a \mathrm{R}$ (zero) $=A O(a \sigma \sqrt{T}-\mu T)$ sebagai berikut:

1. Nilai $\mathrm{VaR}$ (zero) positif dan signifikan berarti terdapat potensi kerugian investasi deposito mudharabah di Bank Syariah Mandiri dimana VaR (mean) lebih besar dari rata-rata nilai gross expected return

2. Nilai $\mathrm{VaR}$ (zero) negatif berarti terdapat potensi profitabilitas investasi deposito mudharabah di Bank Syariah Mandiri dimana VaR (mean) lebih kecil dari ratarata nilai gross expeted return. 
Yudho Prabowo: Analisis Resiko dan Pengembalian Hasil...

\section{B. Hasil Analisis RAROC}

Pendekatan RAROC dalam penelitian ini menunjukkan bahwa jika semakin besar risk adjusted return (RAR), maka semakin meningkat pula bobot RAROC, artinya berbanding lurus. Sedangkan bila semakin besar risk adjusted capital (RC), semakin menurun bobot RAROC sebaliknya, bila semakin kecil risk adjusted capital (RC), semakin meningkat bobot RAROC, artinya berbanding terbalik. Hasil analisis penelitian ini, bobot RAROC pada Bank Syariah Mandiri mencerminkan adanya tingkat efisiensi dan tingkat output yang optimal disebabkan rasio RAR lebih besar dari RC. Dalam pengukuran RAR mempertimbangkan selisih antara rata-rata keuntungan $(\pi)$ dengan rata-rata kerugian (EL), estimasi yang muncul dari variabel RAR dapat diartikan sebagai berikut.

1. Nilai RAR positif dan signifikan berarti terdapat profitabilitas dimana total keuntungan $(\pi)$ lebih besar daripada rata-rata kerugian (EL).

2. Nilai RAR negatif berarti terdapat risiko atau kerugian dimana total keuntungan $(\pi)$ lebih kecil daripada rata-rata kerugian (EL).

Dalam pengukuran RC merupakan selisih antara rata-rata kerugian terburuk atau maksimum (WL) dengan rata-rata kerugian (EL). Perhitungan RC dalam penelitian ini mencerminkan adanya penaksiran atau estimasi kerugian alokasi modal Bank Syariah Mandiri terhadap risiko kredit (credit risk). Hasil analisis RC menunjukkan bahwa expected loss (rata-rata NPF) mengalami peningkatan selama periode 2004-2006. Artinya modal Bank Syariah Mandiri yang sudah disesuaikan dengan besarnya risiko mengalami potensi peningkatan kerugian.

\section{Penutup}

Berdasarkan penjelasan yang telah dikemukakan di atas mengenai risiko investasi deposito mudharabah setelah diukur dengan dengan pendekatan VaR dan pengembalian hasil Bank Syariah Mandiri setelah diukur dengan pendekatan RAROC dapat diambil kongklusi yang terpenting sebagai berikut:

1. Value at Risk $(\mathrm{VaR})$

a. Rata-rata nilai gross expected return terhadap equivalent rate deposito mudharabah berjangka (1, 3, 6 dan 12 bulan) cukup stabil, disebabkan volatilitas nilai VaR (mean) dan VaR (zero) adalah lebih rendah bila dilihat dari rata-rata nilai gross expected return.

b. Investasi deposito mudharabah di Bank Syariah Mandiri cenderung untung disebabkan oleh $\mathrm{VaR}$ (zero) menunjukkan nilai negatif.

c. Investasi deposito mudharabah berjangka 3 bulan tahun 2006 menyatakan bahwa hubungan antara $\mathrm{VaR}$ (zero) dengan rata-rata gross expected return terdapat nilai prospektif artinya low risk bigh return. Hal ini dikaitkan oleh nilai rata-rata gross expected return dan VaR (zero) antara tahun 2006 dengan tahun 2004 dan 2005. Sebagaimana dapat digambarkan pada tabel di bawah. 
Yudho Prabowo: Analisis Resiko dan Pengembalian Hasil...

\begin{tabular}{|l|ll|l||}
\hline $\begin{array}{l}\text { Investasi Deposito } \\
\text { Mudharabah } 3 \text { bulan }\end{array}$ & TAHUN & TAHUN & TAHUN \\
\cline { 3 - 5 } & $\mathbf{2 0 0 4}$ & $\mathbf{2 0 0 5}$ & \multicolumn{1}{l|}{$\mathbf{2 0 0 6}$} \\
\hline Rata-rata Expected Return & 0.073016667 & 0.071225 & 0.073608333 \\
\hline$V a \mathrm{R}(z e r o)=A O(a \sigma \sqrt{ } T-\mu T)$ & -0.005217758 & -0.00240637 & -0.00285975 \\
\hline
\end{tabular}

Investor (deposan) dapat memahami bahwa bobot net return investasi deposito mudharabah berjangka 1, 3, 6 dan 12 bulan diperoleh antara selisih antara rata-rata nilai gross expected return dengan VaR (mean). Artinya nilai rata-rata gross expected return sebesar 7,30 persen dan VaR (mean) sebesar 0,09 persen, maka net return yang dihasilkan adalah 7,21 persen.

2. Risk. Adjusted Return on Capital (RAROC)

a. Analisis RAROC menunjukkan bahwa bobot bersih pengembalian hasil (return) yang telah dipertimbangkan oleh risiko dan pengembalian hasil mengalami potensi penurunan nilai selama periode observasi 2004-2006.

b. Bobot bersih pengembalian hasil terhadap RAROC investasi di Bank Syariah Mandiri menunjukkan bahwa total keuntungan yang telah disesuaikan dengan besarnya risiko lebih besar dari rata-rata kerugian yang tidak diharapkan (unexpected loss). Hal ini berarti BSM mencerminkan adanya tingkat profitabilitas yang tinggi terhadap pemanfaatan dan produktivitas usaha investasi.

Saran yang dapat disampaikan sehubungan dengan hasil penelitian ini adalah sebagai berikut:

1. Adanya upaya untuk meningkatkan pemahaman terhadap investasi Islam dengan saling percaya (trust), saling memberikan manfaat (win-win) dan memegang teguh norma-norma Islam, seperti jujur (transparansi), amanah, tabligh (informatif) dan fathonah (profesional).

2. Investor atau calon investor dan perbankan syariah di Indonesia diharapkan mulai mencoba menerapkan VaR dan RAROC sebagai salah satu upaya untuk memberikan penekanan transparansi dan keseluruhan bobot bersih terhadap tingkat risiko dan tingkat pengembalian hasil.

3. Penelitian ini diharapkan dapat digunakan sebagai referensi penelitian selanjutnya terutama dapat diperoleh hasil yang lebih baik dan bermanfaat.

\section{DAFTAR PUSTAKA}

Al-Suwailem, S. (1996) "Review of Financial Engineering for Islamic Banks," Journal of King Abdulaziz University:Islamic Economics, vol. 8, pp. 65-73.

Anto, Hendrie, M. B. (2003), Pengantar Ekonomika Mikro Islami, Yogyakarta, EKONOSIA.

Antonio, Syafi'i (2001), Bank Syariah: Teori Ke Praktek, Jakarta, Gema Insani, Press. 
Yudho Prabowo: Analisis Resiko dan Pengembalian Hasil...

Arifin, Zainul (2005), Dasar-dasar Manajemen Bank Syariah, Jakarta, Pustaka alvabet.

Brookhart (2007), Mary Bank Asset/Liability Management, The Case for Utilizing Risk-Adjusted Capital as a Key Performance Measure.

Chapelle, Ariane \& Yves Crama, Georges Hübner, Jean-Philippe Peters (2006), Practical Methods for Measuring and Managing Operational Risk in the Financial Sector: A Clinical Study.

Chapra, Umer (1997). Al-Qur'an Menuju Sistem Monoter yang Adil, (teri.), Yogyakarta: PT. Dana Bhakti Prima.

Dym, S. (1997), "Credit Risk Analysis for Developing Country Bond Portfolios: Applying Classical Tools to a New Asset Class," The Journal of Porffolio Management, 99-103.

Experian Scorex, The New Basel Capital Accord Glossary of Terms.

Fatwa Dewan Syariah Nasional Nomor 03/DSN-MUI/IV/2000.

Fred Weston, J. Eugene F. Brigham, Essentials of Finance, Erlangga.

Harper, D. Intoduction to Value at Risk (VAR). (2004), Investopedia. URL.

Iklan Sirkulasi Surat Pembaca, Lebih Untung Inves di Tabungan Syariah, Tuesday, 30 Januari 2007.

James C. Van Horne, John M. Wachowichz, JR. (2005), "Fundamentals of Financial Management", Pearson Education.

Jorion, P. (1996), "Risk2: Measuring the Risk in Value at Risk," Financial Analysts Journal, 47-56.

Jorion, P. (1997). "The New Benchmark for Controlling Derivatives Risk: Value at Risk", Irwin Professional Publisbing.

Karim, Adiwarman (2006), Bank Islam: Analisis Fiqih dan Keuangan, PT Raja Grafindo Persada.

Khan, Tariqullah \& Ahmed, Habib (2001), Risk Management an Analysis of Issues in Islamic Financial Industry. Islamic Development Bank Islamic Research and Training Institute, Occasional Paper no. 5.

Kuncoro, Mudrajad (2004), Metode Kuantitatif Teori dan Aplikasi untuk Bisnis dan Ekonomi, Yogyakarta, UPP AMP YKPN.

Mahadwartha, Putu, Anom (2002), "Konflik Keagenan dalam Kebijakan Penetapan Nilai Value-at-Risk Pada Industri Perbankan”, Manajemen USAHAWAN Indonesia, Lembaga Manajemen Fakultas Ekonomi Universitas Indonesia, Jakarta, No. 09/TH. XXXI.

Milne, Alistair and Onorato, Mario (2007), "Apples and Pears: The Comparison of Risk Capital and Required Return in Financial Institution.

Namora (2006), "Perbandingan Market Performance dan Karakteristik Keuangan Perusahaan Sektor Aneka Industri dengan Sektor Properti - Real Estat, Tesis, Program Studi Magister Manajemen Program Pasca Sarjana Universitas Pelita Harapan Jakarta. 
Yudho Prabowo: Analisis Resiko dan Pengembalian Hasil...

Nurdin, Jayani (1999). Risiko Investasi pada Saham Properti di Bursa Efek Jakarta. JurnalUsahawan, No. 03 Th. XXVIII.

Pichler, S. and Selitsch, K. (1999): A Comparison of Analytical VaR Methodologies for Portfolios That Include Options, Working Paper TU Wien, available at: http:/ /www.gloriamundi.org.

Pontjowinoto, Iwan P. (2003). Prinsip Syariah Di Pasar Modal (Pandangan Praktisi). Modal Publication, Jakarta.

Prokopczuk, M. Rachev S. abd Truck S. (2004), Quantifying Risk in the Electricity Business: A RAROC-based Approach.

Pyle D.H. (1997), “Bank Risk Management: Theory,” Risk Management and Regulation in Banking, 1-13.

Sakti, Ali (2007). Konsep Investasi dalam Islam, Jurnal Ekonomi Islam. 